\title{
How Indigenous and non-Indigenous women look at AIDS: convergences and singularities*
}

\section{O olhar de mulheres índias e não índias sobre a aids: convergências e singularidades La mirada de mujeres indias y no indias acerca del sida: convergencias y singularidades}

How to cite this article:

Silva JBF, Nóbrega RG, Almeida SA, Lima EAR, Silva ACO, Nogueira JA. How Indigenous and non-Indigenous women look at AIDS: convergences and singularities. Rev Esc Enferm USP. 2020;54:e03552. DOI: http://dx.doi.org/10.1590/S1980-220X2018032403552

\section{Joseane Barbosa Freire da Silva ${ }^{1}$ Rafaela Gerbasi Nóbrega ${ }^{2}$ \\ Sandra Aparecida de Almeida ${ }^{1}$ Édija Anália Rodrigues de Lima ${ }^{3}$ Ana Cristina de Oliveira e Silva ${ }^{1}$ Jordana de Almeida Nogueira ${ }^{1}$}

* Extracted from the dissertation: "Aids em contextos diferenciados: o olhar de mulheres índias e não índias", Programa de Pós-Graduação em Enfermagem, Universidade Federal da Paraíba, 2018

${ }^{1}$ Universidade Federal da Paraíba, João Pessoa, PB, Brazil.

${ }^{2}$ Centro Universitário de João Pessoa, João Pessoa, PB, Brazil.

${ }^{3}$ Universidade Federal de Campina Grande, Cuité, PB, Brazil.

\begin{abstract}
Objective: To analyze the way AIDS is configured in the eyes of Indigenous and nonIndigenous women. Method: A descriptive study implementing a mixed approach, conducted in three indigenous villages and in a surrounding municipality. A semistructured interview script was used, with identification data and questions related to the disease perception, the way of seeing and feeling AIDS. The corpus was processed by IRaMuTeQ software and analyzed by Descending Hierarchical Classification, Content Analysis and Word Cloud. Results: A total of 164 Potiguara indigenous women and 386 non-Indigenous women participated. Three classes were formed: "AIDS and its repercussions", "Social aspects, spirituality and attributed feelings" and "Transmission modes". There was a better understanding of the etiology, treatment and AIDS transmission modes among non- Indigenous women, while the content mainly surrounds negative elements such as death, fear, sadness and prejudice among Indigenous women. Conclusion: The knowledge produced in interactions were formed according to the social context and gain its own significance. Such considerations may contribute to the direction of strategic HIV/AIDS control policies focusing on ethnic/cultural specificities.
\end{abstract}

\section{DESCRIPTORS}

Acquired Immunodeficiency Syndrome; Women's Health; Health of Indigenous Peoples; Public Health Nursing. 


\section{INTRODUCTION}

In the multi-contour scenario in which the Human Immunodeficiency Virus (HIV) infection epidemic is presented, the challenge is to induce innovative approaches which accelerate and broaden the control responses of the disease. It is agreed that the scientific advances and knowledge accumulated over the last decades need to be extended to overcome the service coverage gaps $^{(1)}$.

The importance of supporting and expanding access to diagnosing throughout population segments which have historically been left out of the health services system is recognized in order to end the disease occurring at epidemic levels by 2030 . Although there is a $35.5 \%$ reduction in new HIV infections globally over the past 10 years, it is estimated that 22 million people living with HIV still do not have access to treatment ${ }^{(2)}$.

This has been driving global guidelines and calling for greater focus on key and vulnerable populations, including gay men and other men who have sex with men, transgender people, incarcerated persons, sex workers, adolescent girls and young women, prisoners, migrants, injecting drug users, indigenous ethnic groups, children and pregnant women living with HIV, homeless, people with disabilities and those aged 50 and over ${ }^{(1)}$.

Evidently these populations are not uniformly vulnerable or equally affected. Distinct configurations in the course of the epidemic are determined by economic, political, social and cultural components. Therefore, the response framework to epidemic trends must be oriented towards the characteristics that the epidemic assumes. Identifying regional priorities, strengthening local leaders, establishing innovative solutions and driving inclusive strategies are needed ${ }^{(3)}$.

Attention regarding women needs to be redoubled. In the world context, half of the people living with HIV are female. In 2016, 36.7 million people worldwide lived with HIV, of which 17.8 million were women aged 15 and over ${ }^{(2)}$. In Brazil, 882,810 AIDS cases were registered from the beginning of the epidemic until June 2017, with the highest concentration of cases between 25-39 year olds in both genders $-51 \%$ in males and $49 \%$ in females ${ }^{(4)}$.

In addition to biological factors, the AIDS epidemic exposes the sociocultural risks women face. Historicalcultural determinations, moral values, difficulty in negotiating safe sexual practices, restricted access to health services, and protective measures characterize gender inequalities and increasing violence against women ${ }^{(5)}$.

In turn, knowledge about the disease, transmission modes and risk practices do not sufficiently impact preventive attitudes. Preventing HIV infection goes much further. People's beliefs, values and opinions are hybrid, even when belonging to the same culture. Different experiences of certain segments, groups, or even individuals differentiate them in understanding the world and its meaning. For example, introducing preventive practices among women means taking into consideration the way they think about the differences between male and female roles and behaviors, power relations between genders, their social and productive insertion ${ }^{(6-7)}$.

Therefore, the main challenge to be considered is to focus on the contexts and most important production factors of these vulnerabilities. Discriminatory laws and practices that restrict women's equal access to decision-making, education, employment, property, credit or autonomy promote and reinforce these conditions. These inequalities often overlap, multiplying the risks to women in general. The permanence of ethnocentric positions that generate negative feelings, stigma and prejudice is also highlighted, especially when it comes to women discriminated by their ethnic-racial condition, such as indigenous women ${ }^{(8)}$.

Given the vast repertoire which places women's condition as a center for debate and reflection, it is worth highlighting how complex and diverse the demands of this population are, especially when they differ culturally. It is understood that the sociocultural context influences the way the senses are produced, the way these women will appropriate knowledge and express it in their social relations ${ }^{(9)}$. In this aspect, the focus of interest in this study is knowing the meanings attributed to AIDS by Indigenous and non-Indigenous women in the perspective of identifying singularities and generalities in these different contexts.

Given the above, the following questions emerged: What is the knowledge of these women about AIDS? How do these women view AIDS and what are their perspectives on the disease? Do ethnic differences influence the way they look at AIDS?

Considering that a better understanding of the phenomenon can provide healthcare which is more congruent with cultural values, beliefs and practices, the objective of this study was to analyze the way AIDS is configured in the eyes of Indigenous and non-Indigenous women.

\section{METHOD}

\section{StUdDY DESIGN}

A descriptive exploratory study with a mixed concomitant approach type, which enables simultaneously conducting collection and qualitative and quantitative analysis ${ }^{(10)}$.

\section{Population}

The study population was represented by Indigenous women from three villages in the Potiguara Indigenous Special Health District (DSEI-28) and non-Indigenous women living in the municipality of Rio Tinto, Paraiba state, Brazil.

\section{SAMPLE DEFINITION}

The sample population was defined considering the female population aged between 18 and 65 years, being residents in both research scenarios. In the indigenous context, 164 Potiguara women living in three villages 
participated: Monte-Mór, Jaraguá and Silva de Belém. It is noteworthy that the number of observations ( $\mathrm{n}=$ 164) considered the totality of ethnic Potiguara women between 18 and 65 years old $(n=739)$, assuming a significance level of $5 \%$ at the confidence level of $95 \%$ and an anticipated $\mathrm{p}$-value equal to $15.2 \%$, based on the proportion of notified AIDS cases in the Northeast region of Brazil.

It was decided to select non-Indigenous women from the female population of Rio Tinto, a municipality surrounding the indigenous villages. The sample size calculation was based on all women aged between 18 and 65 years (n $=8,050$ ), assuming a significance level of $5 \%$ at the $95 \%$ confidence level and an anticipated p-value equal to $50 \%$, totaling 386 women.

\section{SelECTION CRITERIA}

The investigated groups consisted of the following criteria: being a woman aged between 18 and 65 years old and being available to participate in the study. The sampling process in the indigenous scenario was performed by proportional sharing considering the female population of the villages, in which 66 women in Monte-Mór village were investigated, 64 in Jaraguá village, and 34 in the Silva de Belém village. Participant selection was non-probabilistic by convenience (voluntary participation).

The selection of non-Indigenous women in the municipality of Rio Tinto was non-probabilistic, considering the proportional sharing sample process according to the number of health units in the municipality ( $9 \mathrm{BHU}-$ Basic Health Unit). Thus, 43 women were investigated in each $\mathrm{BHU}$ unit of Conjunto Novo, Palmeiras, Vila Regina, Salema, Rio do Banco, Cravaçu, Tanques and Piabuçu, while there were 42 women at the Cinco Ruas BHU.

\section{Data collection}

A semi-structured interview script with questions about identification was used (group to which they belong, Indigenous or non-Indigenous, age and marital status) and questions related to the disease perception, way of seeing and feeling AIDS. The interviews were conducted individually and recorded, with an average duration of 30 minutes.

\section{DATA ANALYSIS AND PROCESSING}

The 550 interviews were transcribed and coded according to the participant's number, group to which she belonged (Indigenous or non-Indigenous), age and marital status. The corpus was submitted to a refinement to exclude vocabulary repetitions, grouping of words by semantic approximation and composition of a dictionary. The information was sequentially processed by the IRaMuTeQTextual Analysis software ( $\mathrm{R}$ interface for Multidimensional Analysis of Textes and Questionnaires - Version 0.6 alpha 3), which classified the segments according to their respective vocabularies, generating a Descending Hierarchical Classification $(\mathrm{DHC})^{(11)}$.
It was found that the corpus which made up the 550 interviews generated 651 Elementary Context Units (ECUs). The Descending Hierarchical Classification (DHC) retained 501 ECUs, with $76.96 \%$ utilization (minimum retention of $75 \%$ of the text segments is suggested, which guarantees qualification of the corpus $\left.{ }^{(11)}\right)$. The software automatically grouped the classes based on vocabulary and the variables which contributed to forming each class, being selected according to the chi-squared values $\left(X^{2}\right)$.

An interpretative analysis of the corpus took place through the use of Content Analysis (thematic modality) ${ }^{(12)}$, which indicated the convergence of empirical characteristics around three themes, being a posteriori called: a) AIDS and its repercussions; b) Social aspects, spirituality and attributed feelings; c) Transmission modes. The corpus was additionally analyzed by the word cloud method, which consists of grouping and graphically organizing words according to their frequency, thus enabling quick identification of the textual corpus keywords and simple lexical analysis ${ }^{(11)}$.

\section{ETHICAL ASPECTS}

This is a study involving human beings, and as such it obeyed the norms of Resolution 466/2012 of the National Health Council and the determinations of Resolution $304 / 2000$ regarding the special theme of indigenous populations, as well as the Federal Nursing Council Resolution (COFEN 311/2007) regarding the Code of Ethics of Nursing Professionals. The research project was approved by the Research Ethics Committee of the Health Sciences Center of the Universidade Federal da Paraíba, under opinion number 1.984 .528 on March 27, 2017. Each interviewee participated in the research by accepting and signing the Informed Consent Form. Participant statements were coded by the letter "n" plus the underlined Arabic number corresponding to the increasing chronological order of the interviews in order to ensure information confidentiality and anonymity of the participants.

\section{RESULTS}

\section{Characterization of Classes/CATEgories}

In the analysis of the corpus "Women's perspective on AIDS", it was observed from the dendrogram (Figure 1) that the first partition originated two subgroups. The first subgroup consisted of class 2 (Social aspects, spirituality and attributed feelings), and the second subgroup originated from the second partition was composed of classes 1 and 3 (AIDS and its repercussions and Transmission modes).

The class 2 composite subgroup of the dendrogram had the largest representation of Indigenous women, and the class 1 and 3 composite subgroups were most represented by non-Indigenous women. 


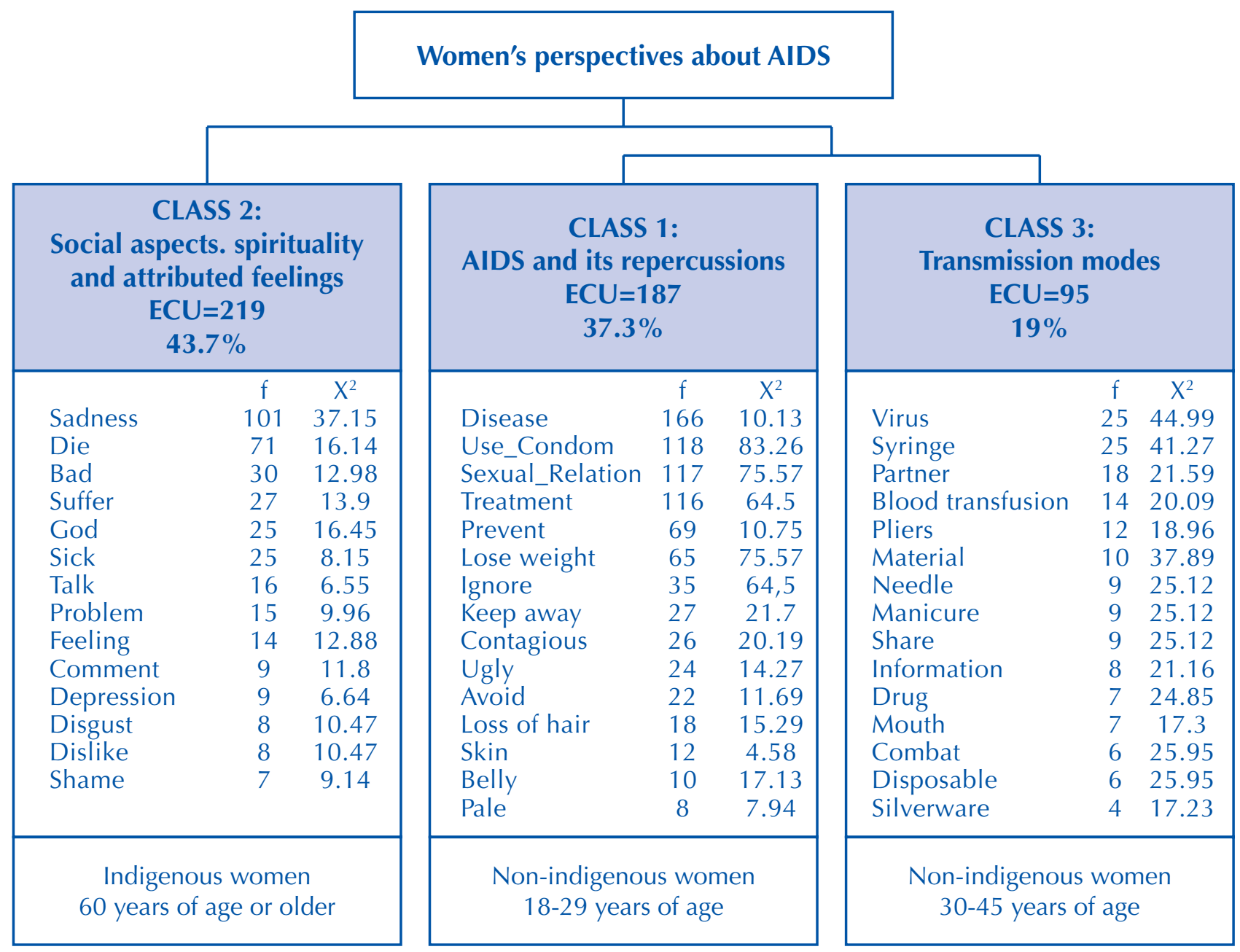

Figure 1 - Dendrogram for class vocabulary distribution according to Descending Hierarchical Classification - Rio Tinto, PB, Brazil, 2017.

\section{INTERPRETIVE ANALYSIS}

Class 1 - AIDS and its repercussions - concentrated $37.3 \%$ of the Elementary Context Units (ECU), predominantly consisting of non-Indigenous women aged between 18 and 29 years. This class presented elements related to understanding AIDS, highlighting it as an ugly, contagious disease transmitted through blood and sexual intercourse, which has preventive and therapeutic resources, although unknown by a portion of the interviewed women. Still, it was possible to identify the existing link between the disease and changes in the physical aspect of a person who has it. The fragility of information about AIDS, as well as beliefs about healing were also evidenced in this class.

AIDS is a sexually transmitted disease (...) it is a virus that contaminates when there is no prevention with condoms and through blood transfusion (...) it is a contagious, complicated disease (...) I don't know what AIDS is (n_181; n_550; n_487; n_484).

I don't have any information about the treatment (...) I've heard about the treatment, but I don't know (...) if it's treated soon it can be cured (...) some say that there is a cure, but I don't know if there is or not, it may exist, but it's probably expensive (n_534; n_508; n_288; n_474).
The physique of those who have AIDS is different (...) a bad thing, turns them ugly (...) leaves them thin, underweight, each day that passes they are closer to death (...) I identify a person with aids if she has no hair (n_442; n_482; n_453; n_495).

Class 2 - Social aspects, spirituality and attributed feelings - collected $43.7 \%$ of the ECU, equivalent to 219 retained and classified ECU. This class was composed of predominantly Indigenous women aged 60 and over. The contents are influenced by social and emotional aspects experienced by the community in facing a person living with HIV. Feelings of sadness, pity, fear and finitude permeated their perception of people living with HIV/AIDS. The imminence of death and the condition of fatality emerged in feelings of fear, rejection and social withdrawal. Belief in behavioral deviations and the designation of the disease as harmful led to feelings of guilt, remorse and self-criticism. Spirituality manifests itself as a way of coping with illness, explanation, and atonement for sins.

A person with AIDS is a sad person (...) in the village, people see those who have AIDS with much prejudice (...) they despise them (...) some are afraid, others are disgusted, others have mercy. I feel compassion because they will die (...) a person with AIDS is a sad person, because they know they will die (n_006; n_164; n_015; n_106, n_100). 
I don't go near a person who has AIDS (...) everyone sees this normal person, because it is a crime and we can't talk about it ... we make friends, but as you know that the person has AIDS, you keep your distance (...) I think it should lead to isolation (n_248; n_001; n_449).

I would feel like the worst person in their place, feeling guilty for not being careful (...) if I had been more careful, what happened wouldn't have happened (...) a person with AIDS suffers without telling anyone out of shame and fear of prejudice (n_160; n_084; n_012).

Only God can heal them because it is an incurable disease. (...) only God can save them. (n_015, n_195).

Class 3 - Transmission modes - concentrated 19\% of ECU, equivalent to 95 retained and classified ECU. This class was predominantly represented by non-Indigenous women aged between 30 and 45 years. The contents were supported by elements related to the transmission mode of HIV.There was a predominance of scientifically disseminated knowledge, however, there is still misleading information about the transmissibility.

It is caught through sex and needles, from something sharp that one contaminated person passes to another (...) the needles have to be disposable, people use a lot of drugs and share needles (n_206; n_207).

I think it can be caught even by touching arms (...) they say it can be caught by the breath and breathing (...) it is transmitted in seats (...) an insect bite can transmit it (n_138; n_494; n_441; n_544).

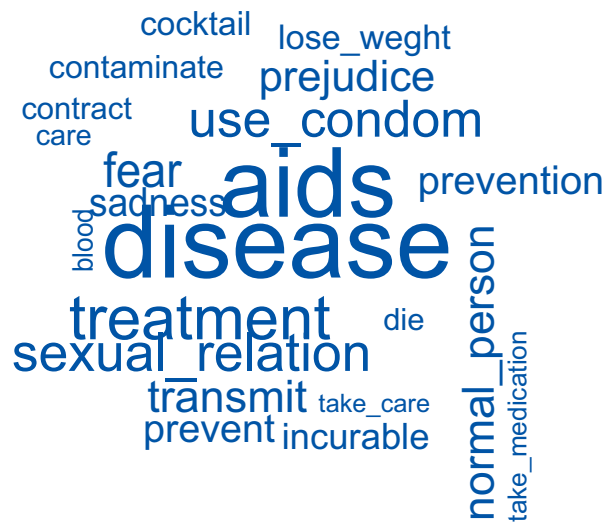

We trust our partners too much and are exposed to AIDS (...) I always ask my husband if he only lives with me, he says yes, that's why I trust him (...) sometimes the partner doesn't accept to use a condom, and because she likes him so much, the woman ends up giving in (n_116; n_146: n_363).

\section{WORD CLOUD}

In comparing the two groups (Figure 2), the words "AIDS" and "disease" were more frequent in the corpus in both the Indigenous and non-Indigenous group of women. It was possible to realize that there is a better understanding of AIDS among non-Indigenous women, presenting contents related to prevention and preventive practices as central elements, as well as the continuity of life through treatment. The following words stood out: treatment, sexual intercourse, condom use and normal person.

The contents among Indigenous women mainly focused on negative elements emerging from the process of thinking about AIDS. They established a direct relationship with death, incurable illness, fear, sadness and prejudice. The fact that indigenous villages are located in areas near the municipality of Rio Tinto does not necessarily mean that these Indigenous women are familiar with the etiology, transmission forms and treatment of AIDS. Although there is a dynamic socialization process, the knowledge produced in the interactions is shaped according to the social context and has its own meaning.

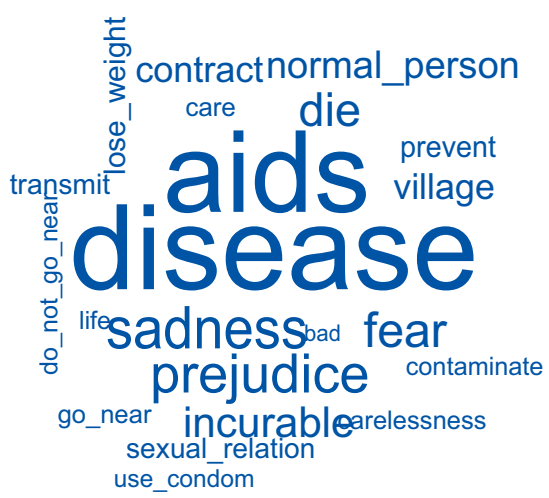

\section{Non-indigenous women}

\section{Indigenous Women}

Figure 2 - Word Cloud for "AIDS" stimulation among Indigenous and Non-Indigenous Women - Rio Tinto, PB, Brazil, 2017.

\section{DISCUSSION}

Physical appearance, social role and negative behaviors permeate the universe of people's imagination about AIDS, in agreement with class one. Multiple interpretations emerged about the disease at the beginning of the epidemic. The sensational information conveyed in the media has greatly contributed to constructing stereotypes linked to people living with HIV/AIDS. Feelings of fear, discrimination and finitude are supposedly perpetuated to the present day ${ }^{(13)}$.
A predominance of negative adjectives are evident in the reports. The imminence of death and the condition of fatality emerge during the speeches in class 1 , and stigmatizing characteristics still remain crystallized. These mainly refer to the period when there was no antiretroviral therapy (ART), symptoms became evident and immunosuppression was externalized by weight loss, pallor, hair loss, among other characteristics ${ }^{(14)}$.

Despite the widespread current dissemination and propagation of campaigns in health media and services, the 
essential notions regarding the disease have not yet been fully understood ${ }^{(15)}$. Knowledge relevant to the pathology is an important and indispensable preliminary item for preventing the disease, but it is solely not enough for behavioral changes to occur. Accessing and capturing information evidently favor identifying risk situations and induces an adoption of preventive attitudes. However, some women cannot identify themselves in facing a vulnerable situation to HIV/AIDS, perhaps due to previous conceptions about the disease and the characteristics restricted to the so-called risk groups. Added to this feeling of invulnerability are the issues of the feminine and pure figure of women, especially in the condition of being a mother, monogamous and elderly ${ }^{(5)}$.

Such positions perpetuate prejudice against minorities, stimulate moral and social stigma, and reinforce feelings of guilt. Manifestations of intolerance and judgments of conduct were evident in class 2 (predominantly Indigenous women). In situations where the diagnosis is known, they sometimes expressed content sensitive to the disease condition, while sometimes they portrayed HIV infection as a result of neglect and postures which are deviant to the social order, depending exclusively on individual choices. As a result, such content generates discriminatory attitudes which involve hostility, segregation and exclusion.

Studies indicate that due to fear of isolation or social rejection, supposedly infected people delay their search for diagnosis and healthcare as negative effects of stigma ${ }^{(16-18)}$. In turn, the possibility of being HIV-positive may lead to questions about their sexual conduct, their multiplicity of partners and to whom these practices are being directed ${ }^{(14)}$.

When asked about "how do you see a person with AIDS", these women claimed to treat them normally, but there was a divergent discourse from individual behavior when "how does the community view a person with AIDS" was investigated. These statements lead one to question whether individual opinions and behaviors are implied in these collective expressions for fear of externalizing discriminatory attitudes.

A study performed with the objective to learn the meanings attributed by female health professionals to the caring process for women with HIV found that a non-discriminatory discourse and care equality also prevails among these health professionals. However, the discourse is ambivalent when they state that they act and react with increased attention during care for women with HIV, fearing an accident with biological material ${ }^{(19)}$.

In facing diseases, especially those socially marked as a death sentence, faith represents another means of protection. Class 2 contents indicated polarity between disease incurability and belief in divine healing. Religion and faith are part of everyday village life when it comes to Indigenous women. It is relevant to point out that the prevention and cure practices that were used by their ancestors among the Potiguaras, such as the use of herbs, medicinal syrups, prayers and spiritual healings are strong traits of their culture.

A study conducted in a northeastern state of Brazil which aimed to analyze the coping mechanisms used by women living with HIV/AIDS, pointed out that religious practices and the belief in a higher being were a source of emotional support and strengthening, being able to provide hopes and expectations of better days, favoring the prognosis and acceptance of the condition ${ }^{(14)}$.

Although religiosity is an important ally of suffering people, it must be viewed with caution, as religiosity itself can generate internal conflicts, exacerbate guilt and the need for self-punishment.

There is a predominance of scientifically disseminated knowledge about the transmission of AIDS in the content of class 3. The official discourse on the disease invariably warns of infection by sex and sharp objects. In addition to sex, blood from transfusions is also an important agent of HIV infection. Although there is strict control in blood banks today, several people became infected as a result of this procedure at the beginning of the epidemic.

On the other hand, uncertainties, confusion and misinformation persist even though there is now greater dissemination of AIDS data through advertisements, campaigns, leaflets and educational work.

Thus, the complex web that involves sociocultural diversity must be considered as a mediator of reflections and actions regarding health problems. Understanding existing beliefs and traditions among indigenous peoples can support developing more effective educational practices on HIV/ $\operatorname{AIDS}^{(20)}$.

One cannot yet generalize indigenous customs and habits, as these are configured according to the organization of their respective communities, where their characteristics are socially constructed according to their singularities. Thus, it is necessary to conduct studies focused on the various ethnicities and contexts in which they are inserted, because indigenous culture does not differ from other cultures which are subject to modification and transformation. The fact that certain ethnicities are close to large urban centers does not make their members less Indigenous, meaning that the acquisition of habits and technologies does not annihilate their origin ${ }^{(21)}$.

The proposition of condom use is still seen as an alleged indicator of infidelity and a source of distrust, reflecting an unnecessary condition when the marital relationship is presumably based on stability. Confidence gained in stable relationships can induce attitudes of individual vulnerability when condom use leads to distrust between the couple, and its (non-use) acceptance as synonymous with trust and fidelity ${ }^{(22)}$.

A hierarchical structure has historically been identified with greater appropriation by men of political power, the power of choice and decision over their affective-sexual and professional life. The man portrays a strong dominating and active figure, while the woman denotes fragility and submission. Such asymmetries result in different oppressive forms, subjecting women to relationships of subordination, fear, fragility, violence and violation of their rights ${ }^{(23)}$.

Given the above and assuming that health practices, including preventive practices, are constantly remodeling and are reevaluated and readjusted in line with social relations, further studies should be conducted focusing on specific 
groups and communities, especially with marginalized populations such as indigenous communities, as one of the main limitations of this study was the absence of updated publications and bibliographic sources which addressed the theme of HIV/AIDS among this population.

It is of fundamental importance that health professionals, including nurses, understand the reality in which they are inserted, as an essential and preliminary item for planning, decision-making and implementing preventive health practices in view of the strong influence that the meanings attributed to previous experiences in the most diverse groups have in facing the health-disease-care process ${ }^{(24)}$. The association of common sense with science is indispensable in seeking promotion and prevention of various health problems, such as HIV/AIDS.

\section{CONCLUSION}

This study made it possible to understand how AIDS is configured from the perspective of Potiguara Indigenous and non-Indigenous women, as well as the ethnic influence of the disease. Convergences between the two groups were identified in all thematic classes. Incorporation of scientific knowledge was observed, especially regarding preventive practices. However, feelings of fear, rejection and misinformation regarding the transmission mode of the disease persist.

The result generated by the word cloud technique showed particularities between the groups and the existence of some ethnic differences in the perception of AIDS. Negative elements supported by common sense conceptions were identified among Indigenous women, while the biomedical paradigm predominates among non-Indigenous women.

It remains a challenge to ensure that Indigenous or non-Indigenous women have tools for socio-cultural empowerment. The knowledge shown about the methods of disease prevention does not effectively ensure adoption of preventive behaviors. Therefore, it is recommended that elements of subjective experience be incorporated, and that information consider the cultural and social values of the contexts in which these women are inserted in order to confront this epidemic.

\section{RESUMO}

Objetivo: Analisar o modo como a aids se configura sob o olhar de mulheres índias e não índias. Método: Estudo descritivo, com abordagem mista, realizado em três aldeias indígenas e em município circunvizinho às aldeias. Utilizou-se de um roteiro de entrevista semiestruturado, constando dados de identificação e perguntas relacionadas à percepção da doença, modo de ver e sentir a aids. O corpus foi processado pelo software IRaMuTeQ e analisado pela Classificação Hierárquica Descendente, Análise de Conteúdo e Nuvem de Palavras. Resultados: Participaram 164 mulheres da etnia potiguara e 386 mulheres não índias. Foram conformadas três classes: "aids e suas repercussões", “aspectos sociais, espiritualidade e sentimentos atribuídos" e "modos de transmissão". Entre as mulheres não índias, há uma melhor compreensão quanto à etiologia, tratamento e modos de transmissão da aids. Entre as mulheres índias, os conteúdos circundam principalmente em elementos negativos, tais como: morte, medo, tristeza e preconceito. Conclusão: Presume-se que os conhecimentos produzidos nas interações se moldem de acordo com o contexto social e ganhem significação própria. Tais considerações podem contribuir para o direcionamento de políticas estratégicas de controle do HIV/Aids com foco nas especificidades étnicas/ culturais.

\section{DESCRITORES}

Síndrome de Imunodeficiência Adquirida; Saúde da Mulher; Saúde de Populações Indígenas; Enfermagem em Saúde Pública.

\section{RESUMEN}

Objetivo: Analizar el modo cómo el sida se configura bajo la mirada de mujeres indias y no indias. Método: Estudio descriptivo, con abordaje mixto, realizado en tres aldeas indígenas y en municipio de las cercanías de las aldeas. Se utilizó un guión de entrevista semiestructurado, en donde figuraban datos de identificación y preguntas relacionadas con la percepción de la enfermedad, modo de ver y sentir el sida. El corpus fue procesado por el software IRaMuTeQy analizado por la Clasificación Jerárquica Descendente, Análisis de Contenido y Nube de Palabras. Resultados: Participaron 164 mujeres de la etnia potiguara y 386 mujeres no indias. Se conformaron tres clases: "sida y sus repercusiones", "aspectos sociales, espiritualidad y sentimientos atribuidos" y "modos de trasmisión". Entre las mujeres no indias, existe una mejor comprensión en cuanto a la etiología, el tratamiento y los modos de trasmisión del sida. Entre las mujeres indias, los contenidos abarcan especialmente los elementos negativos, tales como: muerte, miedo, tristeza y prejuicio. Conclusión: Se presume que los conocimientos producidos en las interacciones se moldeen de acuerdo con el contexto social y ganen significación propia. Dichas consideraciones pueden contribuir a la dirección de las políticas estratégicas de control del VIH/Sida con énfasis en las especificidades étnicas/culturales.

\section{DESCRIPTORES}

Síndrome de Inmunodeficiencia Adquirida; Salud de la Mujer; Salud de Poblaciones Indígenas; Enfermería en Salud Pública.

\section{REFERENCES}

1. Joint United Nations Program on HIV/AIDS. Strategy 2016-2021: on the fast track to the aids [Internet]. 2015 [cited 2018 Mar 23]. Available from: http://www.unaids.org/en/resources/documents/2015/UNAIDS_PCB37_15-18

2. Joint United Nations Program on HIV/AIDS. UNAIDS DATA 2017 [Internet]. 2017 [cited 2018 Feb 21]. Available from: http://www.unaids. org/sites/default/files/medi a_asset/20170720_Data_book_2017_en.pdf

3. World Health Organization. Consolidated guidelines on HIV prevention, diagnosis, treatment and care for key populations [Internet]. Geneva: WHO; 2014 [cited 2018 Feb 20]. Available from: http://apps.who.int/iris/bitstream/10665/128048/1/9789241507431_eng. pdf?ua $=1 \& u a=1$

4. Boletim Epidemiológico HIV/Aids. Brasília: Ministério da Saúde, Secretaria de Vigilância em Saúde, Departamento de DST. Aids e Hepatites Virais. 2017;5(1) 
5. Garcia S, Berquó E, Lopes F, Lima LP, Souza FM. Práticas sexuais e vulnerabilidades ao HIV/aids no contexto brasileiro: considerações sobre as desigualdades de gênero, raça e geração no enfrentamento da epidemia. Demograf Debate [Internet]. 2015 [citado 2018 jul. 09];2(1):417-47. Disponível em: http://www.abep.org.br/ abeporgb/publicacoes/index.php/ebook/article/viewFile/59/57

6. Ceccon RF, Meneghel SN. Iniquidades de gênero: mulheres com HIV/Aids em situação de violência. Physis. 2017;27(4):1087-103. DOI: http://dx.doi.org/10.1590/s0103-73312017000400012

7. Said AP, Seid MF. Serodiscordance and prevention of HIV: perceptions of individuals in stable and non-stable relationships. Interface (Botucatu). 2015;19(54):467-78. DOI: http://dx.doi.org/10.1590/1807-57622014.0120

8. Pfeffer RSA. A contribuição do sincretismo brasileiro para a construção de uma ética global. Conjectura Filos Educ [Internet]. 2013 [citado 2018 jul. 09];18(2):107-21. Disponível em: http://www.ucs.br/etc/revistas/index.php/conjectura/article/view/1510/pdf_134

9. Patrão AL, Mcintyre T, Costa E. Factores de risco psicossociais e sócio-cognitivos para o virus da imunodeficiência humana/síndrome da imunodeficiência adquirida (VIH/Sida) na mulher africana. Rev Port Saúde Pub [Internet]. 2015 [citado 2018 fev. 12];33(2):222-34. Disponível em: http://www.scielo.mec.pt/scielo.php?script=sci_arttext\&pid=S0870-90252015000200012\&lng=pt\&nrm=i\&tlng=pt

10. Santos JLG, Erdmann AL, Meirelles BHS, Lanzoni GMM, Cunha VP, Ross R. Integrating quantitative and qualitative data in mixed methods research. Texto Contexto Enferm [Internet]. 2017 [cited 2019 Mar 28];26(3):e1590016. Available from: http://www.scielo.br/pdf/tce/v26n3/ en_0104-0707-tce-26-03-e1590016.pdf

11. Camargo BV, Justo AM. Iramuteq: um software gratuito para análise de dados textuais. Temas Psicol. 2013;21(2):513-8. DOI: http://dx.doi. org/10.9788/TP2013.2-16

12. Bardin L. Análise de conteúdo. Lisboa: Edições 70; 2011.

13. Antunes L, Camargo BV, Bousfield ABS. Representações sociais e estereótipos sobre aids e pessoas que vivem com HIV/Aids. Psicol Teor Prát [Internet]. 2014 [citado 2018 mar. 10];16(3):43-57. Disponível em: http://pepsic.bvsalud.org/pdf/ptp/v16n3/04.pdf

14. Melo ES, Rozendo CA, Argolo JGM, Queiroz AAFLN, Gir E, Reis RK. Mecanismos de adaptación utilizados por mujeres que viven con VIH/sida. Rev Cuba Enferm [Internet]. 2017 [citado 2018 mar. 02];33(3). Disponible en: http://www.revenfermeria.sld.cu/index.php/enf/ article/view/1308

15. Rufino EC, Andrade SSC, Leadebal ODCP, Brito KKG, Silva FMC, Santos SH. Women's knowledge about STI/aids: working with health education. Ciênc Cuid Saúde. 2016;15(2):9-16. DOI: http://dx.doi.org/10.4025/cienccuidsaude.v15i2.26287

16. Poletto MP, Heck C, Calsa DC, Moskovics JM. Pensamentos automáticos e crenças centrais associados ao HIV/AIDS em indivíduos soropositivos. Temas Psicol. 2015;23(2):243-53. DOI: http://dx.doi.org/10.9788/TP2015.2-01

17. Cardoso JA, Dourado GOL, Moreiras FS, Almeida JS, Alencar JMN, Miranda ABS. Cuidados de saúde mental em serviços especializados de atenção à DST/AIDS. Rev Pre Infec Saúde. 2015;1(2):75-82. DOI: https://doi.org/10.26694/repis.v1i2.3646

18. Caliari JS, Teles AS, Reis RK, Gi E. Factors related to the perceived stigmatization of people living with HIV. Rev Esc Enferm USP. 2017;51:e03248. DOI: http://dx.doi.org/10.1590/s1980-220x2016046703248

19. Porto TSAR, Silva CM, Vargens OMC. Caring for women with HIV/AIDS: an interactionist analysis from the perspective of female healthcare professionals. Rev Gaúcha Enferm. 2014;35(2):40-6. DOI: http://dx.doi.org/10.1590/1983-1447.2014.02.41253

20. Piriz MA, Ceolin T, Mendieta MC, Mesquita MK, Lima CAB, Heck RM. Health care with the use of medicinal plants: a cultural perspective. Cienc Cuid Saúde. 2014;13(2):309-17. DOI: http://dx.doi.org/10.4025/cienccuidsaude.v13i2.20703

21. Carneiro MGC. Espaço, singularidades e memória Guarani Mbyá. Rio de Janeiro: Gramma; 2017.

22. Panarra BACS, Teixeira EPIP, Rodrigues ILA, Ferreira AMR. Vítimas e culpadas: representações sociais sobre mulheres que vivem com HIV. Rev Cuid. 2017;8(3):1887-98. DOI: https://doi.org/10.15649/cuidarte.v8i3.451

23. Peixoto MM, Heilborn ML. Mulheres que amam demais: conjugalidades e narrativas de experiência de sofrimento. Estud Fem. 2016;24(1):45-62. DOI: http://dx.doi.org/10.1590/1805-9584-2016v24n1p45

24. Pontes ALM, Rego S, Garnelo L. O modelo de atenção diferenciada nos Distritos Sanitários Especiais Indígenas: reflexões a partir do Alto Rio Negro/AM, Brasil. Ciênc Saúde Coletiva. 2015;20(10):3199-210. DOI: http://dx.doi.org/10.1590/1413-812320152010.18292014

Financial support

Conselho Nacional de Desenvolvimento Científico e Tecnológico (CNPq). Process no. 311371/2015-9. 